20. サージカルスクラブ（手術時手洗い）に おけるグルコン酸クロルヘキシジン充埃ディスポ ーザブルブラシの評価

刈谷総合病院外科大久保 憲 東邦大学外科学第 3 講座 炭山 嘉伸 草地 信也 東京大学感染制御学教室 小林 寛伊

はじめに

クルコン酸クロルヘキシジンをあらかじめディ スポーザブルブラシに充填した製品 E-Z7479R

（米国ベクトン・ディッキンンン社製）の安全性と 有効性並びに従来法との同等性を評価した。

1. 方法

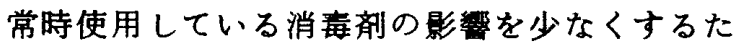
め, 試験は毎週月曜日の就業前に行い,ブラシの 割付けは同一被験者が 2 種類のブラシを使用でき るクロスオーバー法で行った。

被験者は刈谷総合病院の手術部看護婦 24 名と東 邦大学医学部附属病院の外科医師 24 名とした。

被験ブラシは $4 \mathrm{~W} / \mathrm{V} \%$ グルコン酸クロルヘキシジ ンが 10ml 充填されたディスポーザブルブラシ／ス ポンジ(E-Z 7479R ブラシノスポンジ, 以下 BSCH と略）である。対照消毒薬は 4 W/V \%タルコン酸 クロルヘキシジン $10 \mathrm{ml}$ とし，ブラシはディスポー ザブルブラシ $\left(\mathrm{E}-\mathrm{Z}\right.$ Scrub $\mathrm{S}^{\mathrm{R}}$ ブラシノスポンジ・ド ライタイプ，以下 BS dry と略）を用いた。

\section{2. 手掌付着細菌数の測定}

手掌付着細菌の採取は, 手洗い前後の 2 回行い, コロニー数による評価判定を行った。

使用培地は, Trypticase peptone $と$ Phytone peptone を主成分とした PALM-STAMPR medium (日 研生物医学研究所）に0.1 W/V \% Lecithin, 0.7 W/V \% Polysorbate-80を消毒薬不活化剂として混 入した特製培地を用いた。

手洗い前後に手掌を培地に 5 秒間強く押しつけ る方法で細菌を採取し，培羪は $37{ }^{\circ} \mathrm{C} 24$ 時間を原 則として細菌陰性の昜合には48時間後および 96 時間後す継続して判定した。

さらに, 手洗い後の培地でュロニーが出現した 場合には，細菌の同定も併世て行らすのとした。 3.ブラッシングの方法

手洗い時間は3 分間法とし，以下に定める方法 により行った.ブラッシングの回数は, メトロノ
ームを使用して 1 分間 176 往復とした。

ブラッシングに先立ち，素洗いとして $4 \mathrm{~W} / \mathrm{V} \%$ グ ルコン酸クロルヘキシシンを適当量用いて指先か ら上腕 $1 / 2$ までを衛生的日常手洗いに準じて30秒 間洗い，手洗い用減菌水で流した後，再び同様の 方法で 1 分 30 秒間のもみ洗いを行った。

ブラッシングは,ブラシのスポンジ面で指先か ら上腕 $1 / 3$ までにわたり均一に被験薬を塗布する。 次にブラシ面を用いて指先から肘の直上までをブ ラッシングする方法とした。

まず，左手の爪部を 15 秒間，続いて指の間を 15 秒間，手背を 15 秒間，手掌を 15 秒間洗い,同 様に右手を洗い，左右あわせて 2 分間行 5。さら に左右前腕 1/2 をそれぞれ 15 秒間, 残りの1/2を 同様に 15 秒間の計 1 分間ブラッシングする.その 後流水にて时を低く保ちながら洗い流す。

対照群は同様の类洗いる行った後，減菌したデ

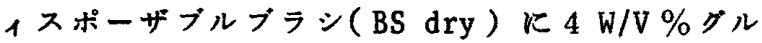
コン酸クロルヘキシジを $10 \mathrm{ml}$ 滴下して, 指先 から順次被験薬と同様の方法でブラッシングする.

4. 成緹

両施設と検討は 2 日間( 1995 年 4 月 17 日, 4 月 24 日)で行った．合わせて 48 名が参加し，2 日間 でかつ両手掌で検討したが，手洗い前の手掌付着 コロニー数が0であった者と両ブラシを使用でき なかった者を脱落として报い，被験ブラシ( $\mathrm{EZCH})$ は 182 検体，対照ブラシ（BS dry）で 182 検体で あった。

手洗い前・後および美のクロスオーバ一解析に おいて，第 1 回目と第 2 回目のデータが時期变化 を示したかとうかについては，第 1 回目（ $\mathrm{n}=90)$ の手洗い前のコロニー数は $261.0 \pm 289.2 \mathrm{CFU} / \mathrm{ha}$

手洗い前後の手掌付着菌

\begin{tabular}{|c|c|c|c|}
\hline 使用ブラシの需霜 & 手洗い茯 & 手洗い陆 & \\
\hline BSCHブラシ $(n=91)$ & $314.89 \pm 330.95$ & $0.14 \pm 0.46$ & $7_{p=0.226}$ \\
\hline B Sdry ブラシ $(n=91)$ & $257.12 \pm 307.80$ & $0.32 \pm 1.14$ & \lrcorner \\
\hline
\end{tabular}

CFU/hand (mean $\pm S O)$

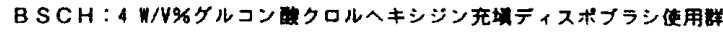
B S dry：ティスボブラシに 4 W/V\% ゲルコン酸ロルヘキシジンを加 使用群

使用培地：消第新不活化到入り PALM-STAMP培地

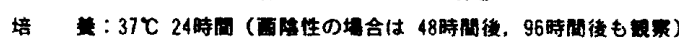

三元呒而分船分析

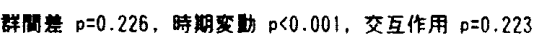




\begin{tabular}{|c|c|c|c|}
\hline & クロ ス集 & 計表 & \\
\hline 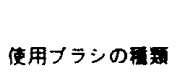 & 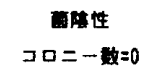 & 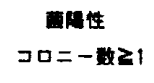 & 各形 \\
\hline BSCHブラシ & 81 円 & 1099 & 91) \\
\hline B Sdry プラシ & 77 甥 & 1487 & 91 成 \\
\hline
\end{tabular}

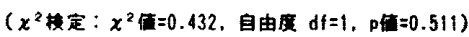

nd (mean 上 SD), 手洗い後のコロニ一数柱 $0.27 \pm$ $1.01 \mathrm{CFU} / \mathrm{hand}$ であり, 第 2 回目 $(n=92)$ では同 様に $310.5 \pm 347.4$ (前) $0.20 \pm 0.71$ (後) となった。 したがって，第 1 回目と第 2 回目とでは両群間に 差はみられない（ $\mathrm{p}=0.299$ ：二元配置分散分析）.

手洗い前後の手掌付着細菌数からみた効果の検 討では，BSCH を使用した手洗い前手掌付着細菌数 は $314.9 \pm 330.9 \mathrm{CFU} /$ hand $(n=91)$, 同様飞BS

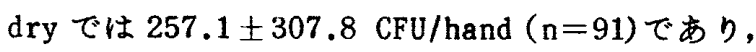
また BSCH を使用した手洗い後の手掌付着細菌数は $0.14 \pm 0.46 \mathrm{CFU} / \mathrm{hand}, \mathrm{BS}$ dry では0.32 $1.14 て ゙$ あり，両ブラシにおける手洗い法には有意差はる られない $(p=0.226)$.

さらに手洗い前と手洗い後のコロニ一数の減少 のパターンに括いて 両群間に差はみられない $(p=0.223)$. ᄂかし両群とすに手洗い後のコロニ数は手洗い前に比較して明かな減少がみられ，時 期変動として有意に手洗い後の菌数は少なくなっ ている $(p<0.001)$.

手洗い後の手掌付着コロニーが認められなかっ たすのと $1 \mathrm{cFU} / \mathrm{hand}$ 以上認められたケースについ て菌陰性となったかどらかを比較してみると，BS CHでは 91 回の手洗いにおいて菌陰性は 81 例，菌 陽性は 10 例であるのに対して, 対照群のBS dry では菌陰性は 77 例, 菌陽性は 14 例であり, 両者 間には有意差は怹められない $\left(p=0.511, X^{2}\right.$ 検定, $\mathrm{X}^{2}$ 値 $=0.432$ ).

手洗い後に検出された細菌は全部で 42株であり， 同定の結果 coagulase negative Staphylococci 27 株, Bacillus sp. 11 株, Corynebacterium sp. 4 株である.グラム陰性桿菌吅よび真菌類は検出 されなかった。

\section{5. 考察}

サージカルスクラブは術者の手指に付着する細 菌が術野に交差感染を起こすことを防止するため の重要な手技である。しかしブラシを用いた過度 のスクラッピングは，微少な皮周損倁をま权き， 細菌の定着を促進して手指を介した交差感染のリ スクを增大させることにつながる可能性がある。

再使用ブラシ（ポリプロピレン製刷毛）による 素洗い後の 3 分間, 4 分間の 2 回のブラッシングと, 素洗い 2 分後のディスポーザブルブラシによる 6 分間 1 回のブラッシングとを比較をした小林の報 告 1)では，ディスポーザブルブラシによる6 分間 1 回のブラッシングによって手洗い効果が低下す る事実は認められていない。そしてさらに再使用 ブラシの睠入費や再使用のための人件費, 使用可 能回数を考慮した時，ディスポーザブルブラシは むしろ経済的であるため，皮届損傷の危険性の 少ないディスポーザブルブラシに切り替えるべき だとしている。

サージカルスクラッブは, 従来では再使用隇菌 ブラシを $2 \sim 3$ 個使用し, 平均 6 分間をかけて手洗 いをするのが一般的であったが，ティスポーザブ ルブラシ 1 個による 6 分間手洗い法の有，用性が示 されささらに 3 分間手洗い法での効果についても 従来法との差が認められなかったとする報告 2.3） に基づき，ディスポーザブルブラシに $4 \mathrm{~W} / \mathrm{V} \%$ ク ルコン酸クロルヘキシジンが充填させてある製品 （BSCH）を使用して 3 分間手洗い法での有用性を 評価してみた。

その結果， BSCH ブラシでは手洗い前と比較した 手掌付着菌数は明かに隇少し，従来のブラシによ る手洗い法と差はみられず，有効な方法であると 考えられる。

文献

1）小林寬伊, 都築正和：ディスポーザブルブラ シを用いた手術時手洗い方法, 手術部医学, $10: 446-448,1989$.

2) 小林寛伊, 大久保憲, 桶口道雄はか：短時間 サージカルスクラッブの検討, 手術部医学, 13 : 458-463,1992.

3) 大久保憲, 炭山嘉伸, 草地信也ほか：サーシ カルスクラッブ（手術時手洗い）におけるポ ビドンョード充填ディスポーザブルブラシの 評価, 手術医学, 16:8-13,1995. 